
\title{
28 Research Square \\ Tropical ecosystem structure in the face of fire, grazing, and climate change
}

\section{Arie Staal}

Egbert H. van Nes

Stijn Hantson

Milena Holmgren

Stefan C. Dekker

Salvador Pueyo

Chi Xu

Marten Scheffer

\section{Video Byte}

Keywords: tropical, ecosystem, forest, savanna, climate change, global warming, wildfire, tree, grass

Posted Date: September 20th, 2019

DOI: https://doi.org/10.21203/rs.2.15157/v1

License: (c) (i) This work is licensed under a Creative Commons Attribution 4.0 International License.

Read Full License 


\section{Abstract}

Tropical ecosystems can transition between forest and savanna but how these transitions are affected by changing rainfall patterns remains uncertain Climate changes interact with local grazing and wildfires to determine the growth of tropical trees and grasses A new study looks at how feedback between wildfires, herbivore grazing, and rainfall variability impacts the amount of tree cover in the tropics Researchers found that fires stabilize savannas under intermediate rainfall values while increasing rainfall variability boosted the potential for sudden transition between forest and savanna A similar phenomenon was found under drier rainfall conditions, but in this case herbivores kept grasslands open Forest-savanna transitions have important implications for ecosystem services and people How tropical forests and savannas will function in the future depends on interactions between rainfall, fires and herbivores Staal A., et al. Resilience of tropical tree cover: The roles of climate, fire, and herbivory. (2018) Global Change Biology. 24: 5096-5109 